\title{
FISH DISTRIBUTION IN THE BA CHE AND TIEN YEN RIVERS
}

\author{
Ta Thi Thuy ${ }^{1}$, Tran Duc Hau,", Nguyen Xuan Huan ${ }^{3}$, Pham Van Long ${ }^{4}$ \\ ${ }^{1}$ Hanoi Metropolitan University \\ ${ }^{2}$ Hanoi National University of Education \\ ${ }^{3}$ VNU University of Science \\ ${ }^{4}$ Ministry of Natural Resources and Environment \\ Received 14 January 2020, accepted 18 May 2020
}

\begin{abstract}
The ichthyo-fauna in the $\mathrm{Ba}$ Che and Tien Yen rivers, northern Vietnam is highly diverse, with a total of 245 species determined. However, data on the distribution of fish species are not sufficiently provided for the whole area. This study was conducted from 2008 to 2011 at 27 stations from the $\mathrm{Ba}$ Che and Tien Yen river basins to determine the distribution of fish species according to different sections of the rivers, water bodies, seasons, and salinity levels. The results show that fish species are distributed mainly in the river (with 210 species), concentrated in the downstream area (with 213 species). Fishes are mainly collected in the dry season when the salinity level of river is high, due to seawater intrusion which also brings in 160 species of marine fish. This shows that fish distribution in the research areas is mainly dominated by the presence of marine species. While for freshwater fish, it is clearly affected by the mountainous features. Apart from the common characteristics sharing between the two river basins, but the number of both freshwater and marine fish species in the Tien Yen river are larger than those of $\mathrm{Ba}$ Che river, which is related to fresh water surface, river morphology, the width and location of the estuary to the sea. The downstream area is home to the fish species recorded in the Red Data Book of Vietnam and the complementary species for Vietnam, while the middle and upstream of the rivers may offer a high potential of biodiversity, with many possibly new species for science. These are important data for the conservation and sustainable development of fish resources in the $\mathrm{Ba}$ Che and Tien Yen river basins.
\end{abstract}

Keywords. Ba Che and Tien Yen rivers, distributional pattern, estuary, migratory fish, salinity.

Citation: Ta Thi Thuy, Tran Duc Hau, Nguyen Xuan Huan, Pham Van Long, 2020. Fish distribution in the Ba Che and Tien Yen rivers. Academia Journal of Biology, 42(2): 41-53. https://doi.org/10.15625/2615-9023/v42n2.14782.

*Corresponding author email: hautd@hnue.edu.vn

C2020 Vietnam Academy of Science and Technology (VAST) 


\section{INTRODUCTION}

$\mathrm{Ba}$ Che and Tien Yen are the two largest rivers in Quang Ninh Province, which have unique estuarine traits to northern Vietnam. The two estuaries have large tidal flats with an average tidal range of approximately 3-4 $\mathrm{m}$ (Vu Trung Tang, 2009). Accordingly, the systems contain a diverse range of aquatic organisms. Previous researchers reported a total of 245 fish species in the two river basins (Tran \& Ta, 2014). Also, scientific values and the role of fish resources as well as status, causes to the declining of fish diversity and fisheries information have been provided (Tran \& Ta, 2014). Ta Thi Thuy et al. $(2010,2011)$ provided a list of fish in Tien Yen River from Tien Yen District and fish distributional patterns according to sections of the river and to seasons in the $\mathrm{Ba}$
Che River. Tran \& Ta (2014) reported the distribution of endangered fishes in the two river systems, but there were not any discussions and evaluations. Recently, Ta et al. (2018) have reported species composition of fish in the Tien Yen estuary, but without any information about their distribution. The present paper attempts to elucidate distributional patterns of fish in the two rivers, contributing to fundamental scientific data for the conservation and sustainable development of fish resources.

\section{MATERIALS AND METHODS}

Fish samples were collected at 27 stations from the Ba Che (1-14) and Tien Yen (15-27) Rivers in Quang Ninh and Lang Son Provinces (Figure 1). Eleven field surveys (110 days) were conducted in the rainy and dry seasons from 2008 to 2011.

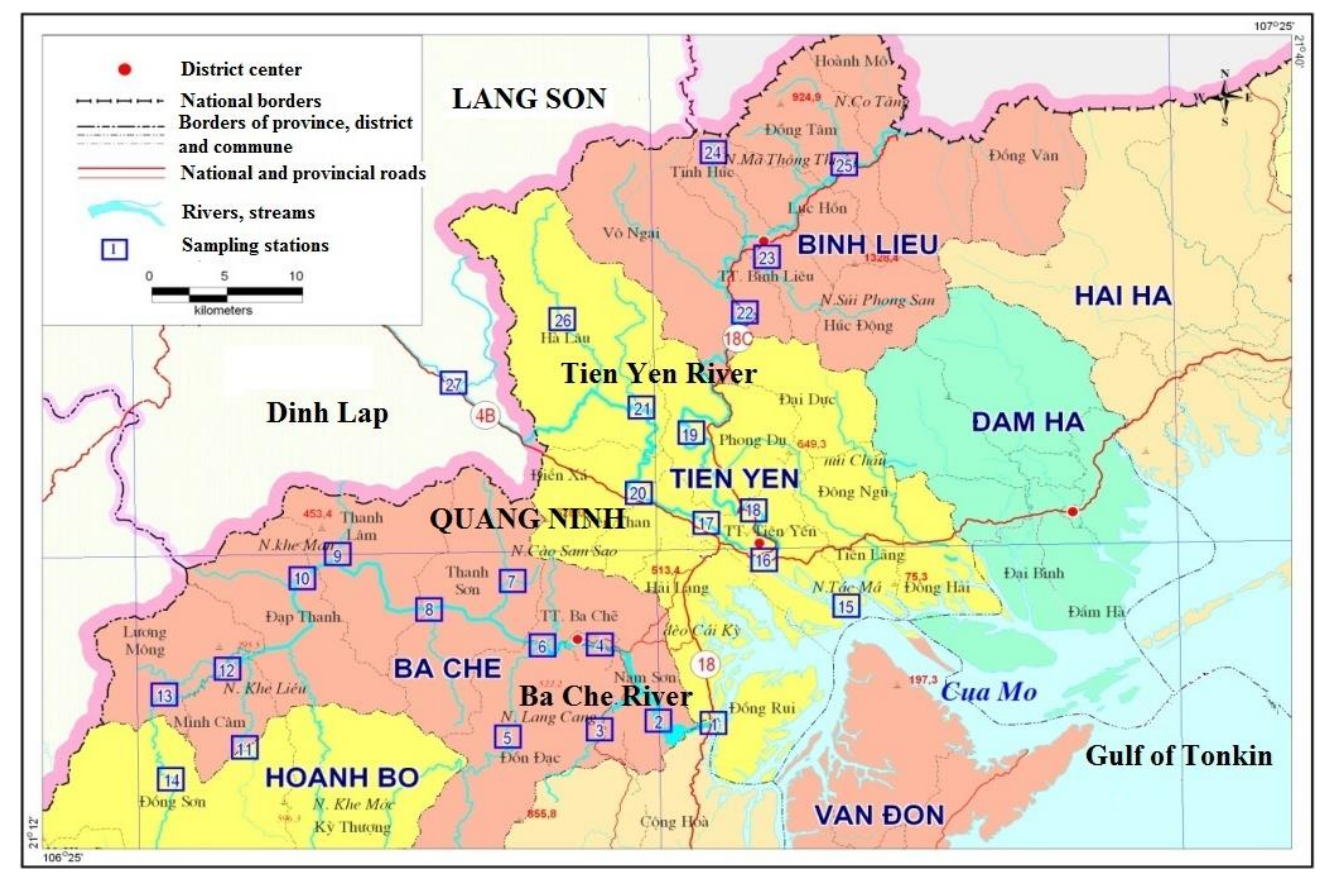

Figure 1. Sampling sites in the $\mathrm{Ba}$ Che and Tien Yen Rivers

Notes: 1: Ba Che bridge; 2: Nam Son; 3: Khe Coc; 4: Ba Che Weir; 5: Don Dac; 6: Khe Tam; 7: Khe Loong Ngoai; 8: Khe Nhang; 9: Khe Xa; 10: Dap Thanh; 11: Minh Cam; 12: Luong Mong; 13: Khe Tun; 14: Tan Oc; 15: Mui Chua; 16: Tien Yen Weir; 17: Yen Than; 18: Khe Soong; 19: Phong Du; 20: Dien Xa; 21: Bac Lu; 22: Khe Lanh; 23: Binh Lieu Town; 24: Tinh Huc; 25: Dong Tam; 26: Ha Lau; 27: Khe Gieng.

The Ba Che River (Quang Ninh) has a length of $79 \mathrm{~km}$, and the Tien Yen River
(Quang Ninh and Lang Son) is somewhat longer (ca. $82 \mathrm{~km}$ in length), and both of them 
flow into the Gulf of Tonkin via Cua Mo (Figure 1). In spite of several similarities, they have some differences in flowing directions, length and width of rivers and estuaries, saline invasion, probably leading to diversity in number of species and distributional patterns.

Sampling sites, method of collection, sample preservation and measurements of water parameters followed to those of Ta Thi Thuy et al. $(2010,2011)$ and Tran \& Ta (2014). Fish bought from local markets were checked carefully about sampling sites for understanding of distribution patterns. List of fish and identification are in accordance with Tran \& Ta (2014). Types of migratory fish followed Froese \& Pauly (2019). Three sections of river, downstream, middle area and upstream followed to those of Nguyen Van Au (1997) and Vu Trung Tang (2008). As for the study sites, the downstream area includes stations 1-4 \& 15-17; middle area 5-8 \& 18-21, and upstream 9-14 \& 22-27 (Tran \& Ta, 2014). Jaccard similarity index about species composition between stations, sections of rivers, and between the two rivers was determined by PAST 3.25 (Hammer et al., 2001).

\section{RESULTS AND DISCUSSION}

\section{Spatial distributions}

\section{Rivers}

A total of 220 species of fish were found in the Tien Yen River, being higher than those from the $\mathrm{Ba}$ Che River (160 species). A number of marine and freshwater fish species from the Tien Yen and $\mathrm{Ba}$ Che Rivers were $145 \& 74$ and $93 \& 67$, respectively. Among 220 species, 135 species were found in the both rivers, 85 only in the Tien Yen and 25 in the Ba Che (Figure 2). Due to similarities in river morphology, weather conditions and topography (they are categorized as small river types and dominated by mountainous terrain), 55 freshwater fish species were collected commonly from the two rivers. Differences in a total of freshwater fish in the $\mathrm{Ba}$ Che and Tien Yen Rivers (67, vs. 74) probably is related to the freshwater surface area, such as river densities (1.11, vs. 1.34); meandering slope (1.78, vs. 2.48) and the number of tributaries (0, vs. 6) (Tran Tuat et al., 1987). Meanwhile, the difference in the number of marine fish species was due to deeper saline intrusion into the Tien Yen River, which has a wider estuary and its direct connection to the sea via Cua Mo in the Tien Yen River. On the other hand, the Ba Che estuary is located far from the sea and blocked by Dong Rui island (Figure 1). Thus, the Tien Yen estuary is a more suitable home for residents and feeding of marine fish than the Ba Che estuary.

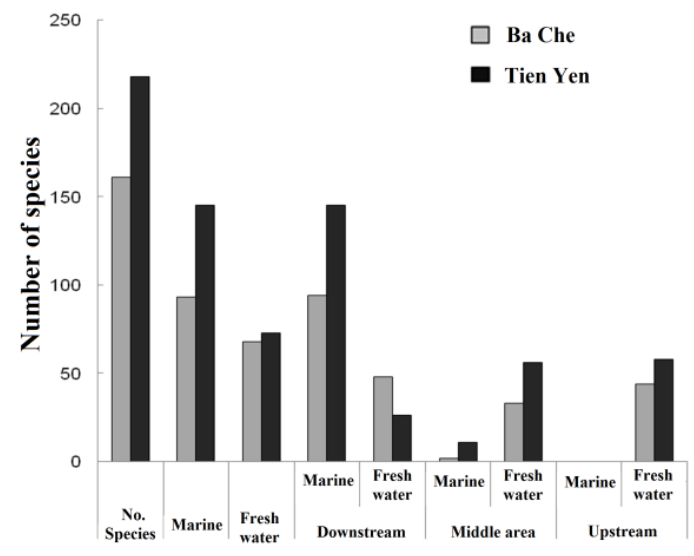

Figure 2. Distribution of fishes in different sections of the $\mathrm{Ba}$ Che and Tien Yen rivers

\section{Sections of rivers}

Fish distribution according to the sections of rivers was different in the study site. They were mainly distributed in the downstream area with 213 species; 77 species in the middle area and 67 species in the upstream (figure 2). Distribution of fish in the upstream area in the Ba Che River was already reported (Ta Thi Thuy et al., 2011). A greater diversity of fish in the downstream area could be due to the invasion of marine fish for feeding. In the upstream area, however, less diverse fish species is related to the steep terrain and valleys, which are often out of water in the dry season, and many areas remained deep pools. In the rainy season, the rivers and streams flow swiftly and the water is turbid.

Regarding to the sections of rivers, 156 species (accounting for 63.9\%) were 
distributed only in the downstream; followed by 40 species $(16.3 \%)$ of widely distributed fish in all three sections of rivers; 17 species $(6.8 \%)$ in both the middle and upstream; 16 species $(6.6 \%)$ in the middle and downstream; 10 species $(4.0 \%)$ in the upstream; 6 species $(2.5 \%)$ in the middle area; and only 2 species $(0.82 \%)$ in both the up- and downstream.

Typical fish species in the downstream were from Carcharhiniformes, Rajiformes, Albuliformes, Elopiformes, Clupeiformes, Syngnathiformes, Scorpaeniformes, Pleuronectiformes and Tetraodontiformes, with 30/40 families of Perciformes as well as species of Gobiidae. Typical fish species in the middle and upstream areas were from Cypriniformes, Siluriformes, Osmeriformes (Plecoglossus altivelis), Synbranchiformes; sub-orders Anabantoidei, Channoidei and Rhinogobius. In the middle and downstream areas, there were a mixture between freshwater and marine fishes, but marine fish became dominant in the downstream, and freshwater fish were dominant in the middle area. The upstream area was the place for freshwater fish species only (figure 2). These findings are consistent with other studies (Dang Ngoc Thanh \& Ho Thanh Hai, 2007; Duong Quang Ngoc, 2007). According to Nelson (2006), species from the order Perciformes and family Gobiidae have the broadest distributional range.

\section{Water bodies}

Fish were mainly distributed in rivers, with 210 species (176 species only found in this water body); followed by the streams, with 58 species ( 23 species only found in this water body) and the lowest number in rice field, ponds and lakes, with 23 species (10 species only found in this water body). The least diverse fish species in the stillness habitat (rice field, ponds and lakes) was due to shallow water depth, low oxygen content, large water temperature fluctuations and frequently influenced by humans. On the other hand, the most abundant fish species in rivers is related to the stable water levels, abundant food supplies and especially large numbers of marine fish entering the river.
Ten species/subspecies distributed in all three water bodies were Opsariichthys hainanensis, Spinibarbus hollandi, Carassius auratus auratus, Cyprinus carpio, Cobitis sinensis, Misgurnus anguillicaudatus, Traccatichthys pulcher, Pterocryptis cochinchinensis, Anabas testudineus and Macropodus opercularis. Twenty five species were found in 2 of 3 water bodies $(22$ species in rivers \& streams, 2 species in streams \& rice field, ponds and lakes, and 1 species in rivers \& rice field, ponds and lakes). Fish distributed in streams (low water temperature, fast water current, many rapids, high oxygen concentration, which are suitable for growth and development of fish that are highly specialized to live in strongly flowing water environment) were from Rhinogobius, subfamilies Danioninae, Gobioninae, Barbinae and families Balitoridae, Bagridae and Sisoridae. Typical fish species distributed in rice field, ponds and lakes were from subfamilies Leuciscinae and Hypophthalmichthyinae; families Cobitinae, Siluridae, Cichlidae, Anabantidae and Belontidae.

The number of freshwater fish species inhabiting stillness waters were few and typical species in mountainous areas were predominant. In the study site, two species were from sub-families Cultrinae (Pseudohemiculter dispar and Sinibrama affinis). Nguyen Van Hao \& Ngo Sy Van (2001) and Nelson (2006) indicating that the species of Cultrinae in Cyprinidae do not prefer living in a strong water current environment, which are different from species of sub-family Barbinae that are typical for mountainous areas. This case relates to the topography and hydrology of the rivers (short rivers, large slope,...) in the study site.

Figures 3, 4 show the relationship of species composition between stations, sections of the river, water bodies, river basins and seasons. Basically, high similarity was observed among stations in the downstream (stations 1-2, 15-17), such similarities were not seen in the middle and upstream areas. Although station 4 is in the downstream, fish composition pattern was completely different 
from other stations in the downstream and rather similar to that of station 18 in the middle area with the equivalent index of 0.38 . This uniqueness of station 4 is due to having more typical freshwater fish species shared with station 18 , and less marine fish species shared with other stations in the downstream (only 27/76 species in station 4, accounting for $32 \%$, vs. 160/245 species in the study site, accounting for $65 \%$ ) (Table 1). Station 24 (in the upstream) was also different from other stations in the middle and upstream areas. There were 16 species distributed in this station, but 1 species (Schistura incerta) was not found in other stations, and 3 species occurred in only two other stations. Furthermore, Station 3 (in the downstream) was close to the other stations in the middle and upstream (Figure 3). Sampling sites in station 3 were short streams, directly flow into the main river, without saline environments, thus no marine fish were recorded herein, which is different from other stations in the downstream areas.
High similarities were found amongst stations in the middle (stations 5-8 and upstream 11-14 and 22-27) from the same or different river basin (Figure 3). This result support the above assumptions as fish are adapted to environments in different sections of the rivers, in different water bodies and fish composition are somewhat interfering with distributional areas, especially between the middle and upstream.

Three water bodies (rivers, streams and rice field, ponds and lakes) showed different fish distribution patterns. The rice field, ponds and lakes with the presence of species preferring to static water environment and low oxygen concentration were different from those in rivers and streams (Figure 4). The streams were close to middle and upstream areas while rivers were close to downstream in the dry season (Figure 4), hence fish distributions in the streams and rivers were different, too. This data proves that fish were dominant in the dry season and the downstream of the Tien Yen River.

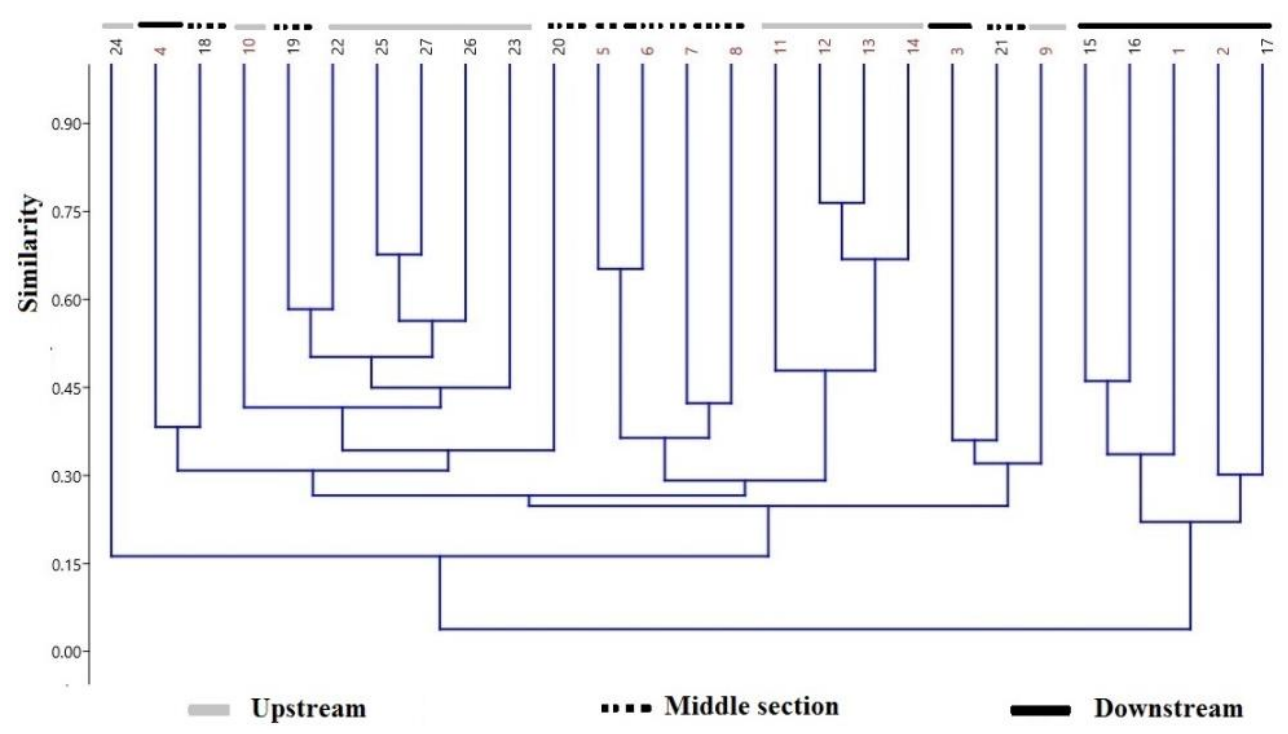

Figure 3. Similarities of species composition between stations from sections of the Ba Che and Tien Yen rivers. Numbers from 1 to 27 donate the sampling stations (see Figure 1)

\section{Seasonal distribution}

While 202 species of fish were collected mainly in the dry season, 136 species in the rainy season and only 94 species in both seasons. Seasonal occurrence of fish differed from sections of rivers and types of water bodies (Figures 4, 5). A number of fish 
species in the downstream in the dry season, rainy season and in both seasons were 166, 112 and 69, respectively. In the dry season, a number of fish species in the middle section and upstream were similar (66 and 57 species). However, in the rainy season or in both seasons, a number of fish species in upstream were higher than those in the middle section (41, vs. 28 in the rainy season; 32, vs. 17 in both seasons).

Regarding to water bodies, fish occurred abundantly in rivers during the dry season (Figure 4) as almost all marine fish entered into the river (166 species in the dry season, 115 species in the rainy season and 76 species in both seasons (Figure 5)). The same tendency was also found in rice field, ponds and lakes; higher number of fish species occurred in the dry season, but there were few differences in the number of fish species according to seasons. The number of fish species in rice field, ponds and lakes in the dry season, rainy season and in both seasons were 20, 15 and 12, respectively (Figure 5). This results shows that seasonal changes of the number of fish species in rivers were higher than the two other water bodies, primarily due to the influence of seasonal entering of marine fish into river mouths and the downstream areas.

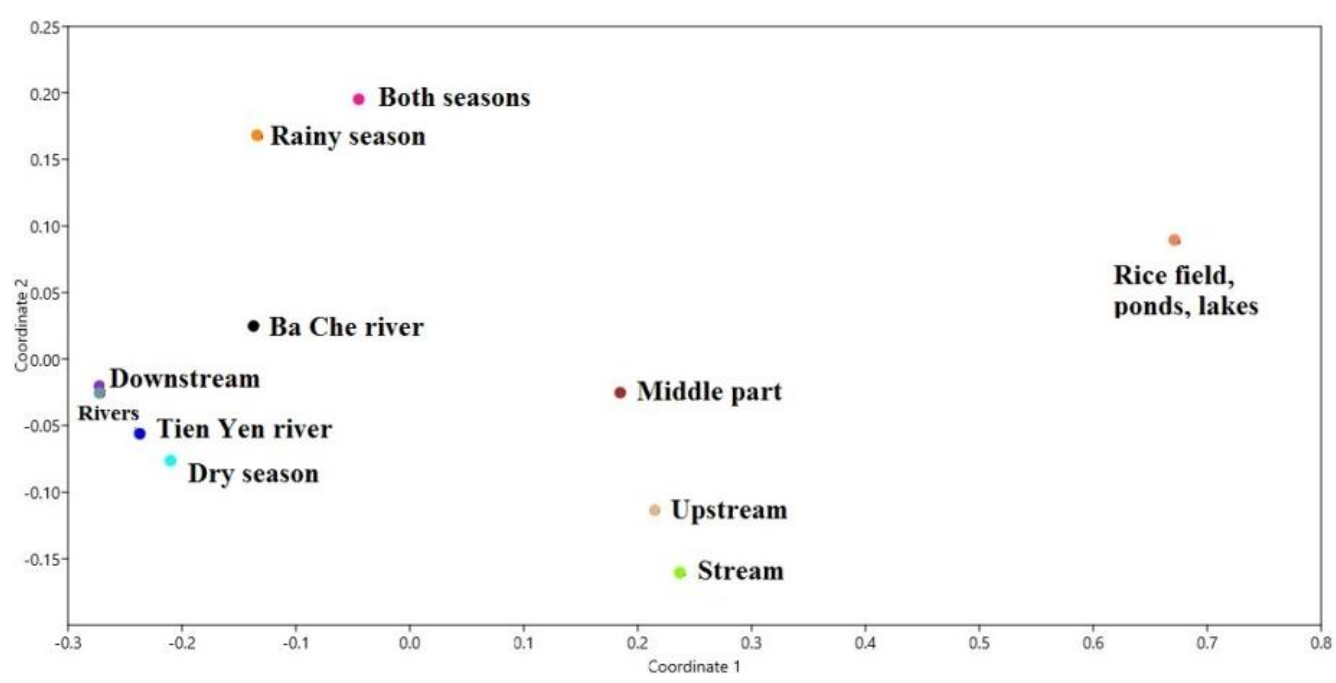

Figure 4. Similarity of fish species composition between water bodies, sections of river and seasonal occurrence in the study site

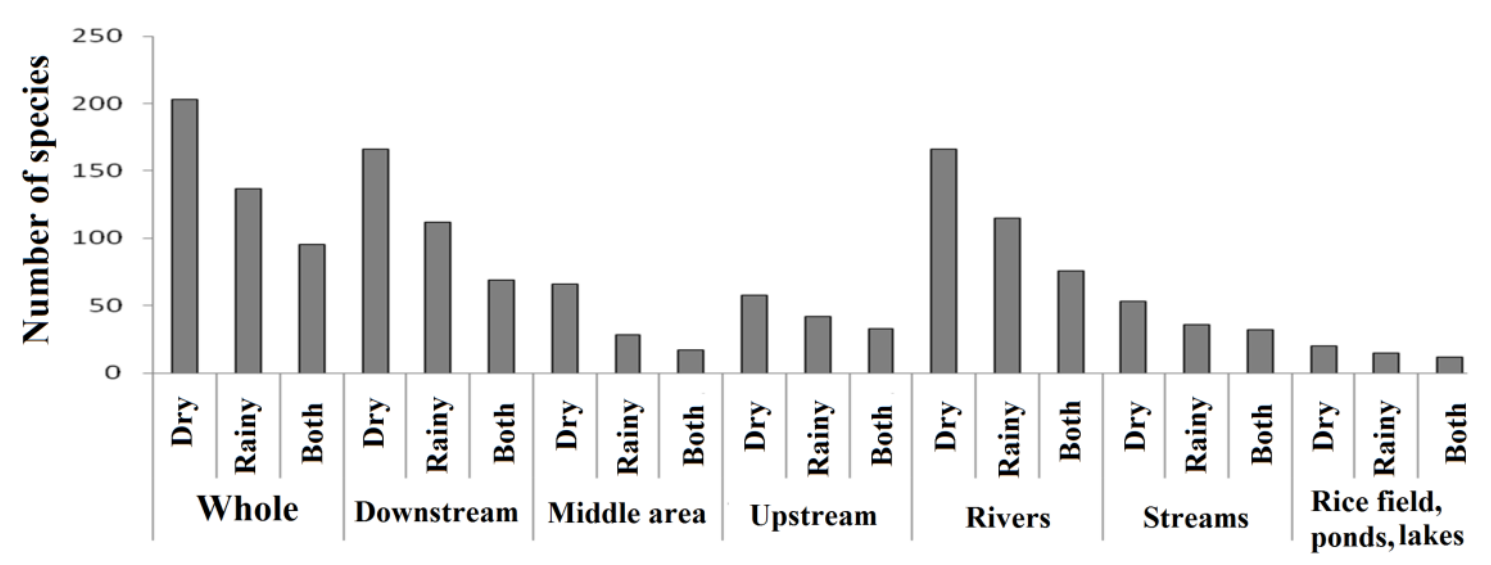

Figure 5. Seasonal occurrence of fish in the $\mathrm{Ba}$ Che and Tien Yen rivers 


\section{Distribution of marine fishes}

\section{Species composition}

Amongst 245 species in the study site, 160 were marine fish ( 3 cartilaginous fish and 157 bony fish) (Froese \& Pauly, 2019). From 20 orders, excluding three orders Cypriniformes, Characiformes and Synbranchiformes that did not have marine fish, Perciformes were the most diverse in the number of marine fish, with 103 species $(64.4 \%$ of the total marine fish in the study site). Amongst 79 families, Gobiidae was the most dominant in number of marine fish, with 18 species, and 24 families had only 1 species each. Such diversity of marine species from order Perciformes and family Gobiidae was also reported in the previous work ( $\mathrm{Vu}$ Trung Tang, 2009). In the study site, the number of marine fish families were high, but the number of genera in each family as well as the number of species in each genus were low. This reflects a typical characteristic of marine ichthyo-fauna in the tropical region (Ministry of Fisheries, 1996). Amongst 17 orders that had marine species, the percentages of marine fish species in the total of fish species from each order of Perciformes, Beloniformes and Siluriformes were $84.4 \%, 75.0 \%$ and $13.3 \%$, respectively, while all species in other 14 orders were marine fish. Hence, marine fish were predominant compared to freshwater fish in the study site.

\section{Distribution by sections of rivers}

While 149 species of marine fish were mainly distributed in the downstream, 11 species were found in the middle section but none in the upstream (Table 1). Higher diversity in the number of fish species in the downstream are as follows: 69 species in $\mathrm{Ba}$ Che bridge, 34 species in Nam Son, 123 species in Mui Chua and 120 species in Tien Yen weir. These stations had a high and relatively stable salinity, a rich food area, where could be utilized as feeding and nursery ground for marine animals, including fish $(\mathrm{Vu}$ Trung Tang, 2009; Tran \& Ta, 2016; Tran Duc Hau \& Pham Thi Thao, 2017; Tran et al., 2018b).

\section{Intrusion in river systems}

Of 160 marine fish species, 47 could enter into the lower reaches of the estuary (stations $\mathrm{Ba}$ Che bridge and Mui Chua). Although salinity is high and nearly stable (ca. $20-27 \%$ ), in the rainy season, this value in the lower reaches of the estuary is frequently changing due to the river discharge. For instance, salinity in Mui Chua during the rainy season was 3-26\%. This situation might influence the occurrence of fish, especially of species that are only distributed in this area. Amongst 47 species occurring in this area, 32 were collected only in the dry season, 12 only in the rainy season and 3 in both seasons (i.e., A. lacunosus, $H$. valenciennei and $O$. fasciolatoceps) (Table 1). Larvae and juveniles of $H$. valenciennei in the Tien Yen estuary occurred from April to November and utilized this estuary as their nursery ground (Tran et al., 2016).

Due to the deep intrusion of salinity (ca. $15 \mathrm{~km}$ at $\mathrm{Ba}$ Che weir in the Ba Che River; 20 $\mathrm{km}$ at Yen Than and $15 \mathrm{~km}$ at Khe Soong hydropower plant in the Tien Yen River), 113 marine fish species could enter deeply into the rivers for feeding and reproduction (Table 1). Saline intrusion into rivers and the number of fish species according to stations and seasons are shown in table 2. The Tien Yen River had a deeper intrusion and higher salinity than the $\mathrm{Ba}$ Che River, and the salinity in the dry season was higher than the rainy season at the respective stations.

Intrusion distance of each species depends on saline tolerant limits and varies seasonally. Thus, there were difference in the number of species, seasons and intrusion distance of marine fish between $\mathrm{Ba}$ Che and Tien Yen Rivers (Table 2). A number of marine fish entered in both seasons in the Tien Yen were higher than that in $\mathrm{Ba}$ Che River (19, vs. 11). Furthermore, the number of intrusion fish species decreased from the downstream to middle area, and was lower in the rainy season.

Of 113 intrustion marine fish species, 11 could reach to the middle area and 102 were 
limited in tidal zones. The farthest intrusion species in the $\mathrm{Ba}$ Che River was $E$. melanosoma at Khe Tam in the dry season, ca. $20 \mathrm{~km}$ from the river mouth, and in the Tien Yen River was $A$. viridipunctatus at Dien $\mathrm{Xa}$ in the rainy season, ca. $25 \mathrm{~km}$ from the river mouth. Duong Quang Ngoc (2007) reported that $E$. fusca could migrate upstream of the Ma River, ca. $70 \mathrm{~km}$ from the river mouth, but the farthest distance recorded of this species in the present study could be collected at Ba Che weir (ca. $15 \mathrm{~km}$ ) and Tien Yen weir (ca. $10 \mathrm{~km}$ ).

Table 1. List of marine fishes entering into the $\mathrm{Ba}$ Che and Tien Yen rivers

\begin{tabular}{|c|c|c|c|c|c|c|c|}
\hline \multicolumn{8}{|c|}{ Species occurring only in the lower reaches of the estuary (Ba Che bridge, Mui Chua) } \\
\hline$\neq$ & Scientific name & 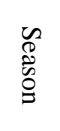 & 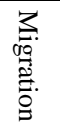 & $\neq$ & Scientific name & $\begin{array}{l}\tilde{D} \\
\mathbb{0} \\
\tilde{0} \\
\mathscr{\Xi}\end{array}$ & 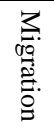 \\
\hline 1 & Rhizoprionodon acutus & $\mathrm{D}$ & $\mathrm{Am}$ & 25 & Alepes djedaba & $\mathrm{D}$ & $\mathrm{Am}$ \\
\hline 2 & Dasyatis bennetti & $\mathrm{R}$ & & 26 & Scomberoides lysan & $\mathrm{D}$ & \\
\hline 3 & Elops saurus VU & $\mathrm{D}$ & $\mathrm{Am}$ & 27 & S. tala & $\mathrm{D}$ & \\
\hline 4 & Albula vulpes $\mathrm{VU}$ & $\mathrm{D}$ & Am & 28 & Leiognathus dussumieri & $\mathrm{D}$ & $\mathrm{Am}$ \\
\hline 5 & Muraenichthys gymnopterus & $\mathrm{R}$ & & 29 & Secutor insidiator & $\mathrm{D}$ & $\mathrm{Am}$ \\
\hline 6 & M. melabonensis & $\mathrm{R}$ & & 30 & Lutjanus argentimaculatus & $\mathrm{D}$ & \\
\hline 7 & Pisodonophis boro & $\mathrm{R}$ & An & 31 & Eleutheronema tetradactylum & $\mathrm{D}$ & $\mathrm{Am}$ \\
\hline 8 & Muraenesox cinereus & $\mathrm{R}$ & & 32 & Omobranchus fasciolatoceps & DR & \\
\hline 9 & Ilisha melastoma & $\mathrm{D}$ & $\mathrm{Am}$ & 33 & Butis koilomatodon & $\mathrm{D}$ & $\mathrm{Am}$ \\
\hline 10 & Coilia mystus & $\mathrm{R}$ & $\mathrm{Am}$ & 34 & Tridentiger trigonocephalus & $\mathrm{R}$ & $\mathrm{Am}$ \\
\hline 11 & Encrasicholina zollingeri & $\mathrm{D}$ & & 35 & Acanthogobius flavimanus & $\mathrm{R}$ & $\mathrm{Am}$ \\
\hline 12 & Stolephorus indicus & $\mathrm{D}$ & An & 36 & A. stigmathonus & $\mathrm{D}$ & $\mathrm{Am}$ \\
\hline 13 & Atherinomorus lacunosus & DR & $\mathrm{Am}$ & 37 & Acentrogobius chlorostigmatoides & $\mathrm{R}$ & $\mathrm{Am}$ \\
\hline 14 & Hypoatherina valenciennei & DR & $\mathrm{Am}$ & 38 & Glossogobius sparsipapillus & $\mathrm{D}$ & $\mathrm{Am}$ \\
\hline 15 & Hippichthysheptagonus & $\mathrm{D}$ & $\mathrm{Am}$ & 39 & Gnatholepis calliurus & $\mathrm{D}$ & \\
\hline 16 & Syngnathus cyanospilos & $\mathrm{D}$ & $\mathrm{Am}$ & 40 & Oxyurichthys papuensis & $\mathrm{D}$ & \\
\hline 17 & Sebastiscus marmoratus & $\mathrm{D}$ & & 41 & Scartelaos histophorus & $\mathrm{D}$ & $\mathrm{Am}$ \\
\hline 18 & Paracentropogon rubripinnis & $\mathrm{R}$ & & 42 & Trypauchen vagina & $\mathrm{R}$ & $\mathrm{Am}$ \\
\hline 19 & Vespicula trachinoides & $\mathrm{D}$ & & 43 & Sphyraena japonica & $\mathrm{D}$ & \\
\hline 20 & Trachicephalus uranoscopus & $\mathrm{D}$ & & 44 & Lepturacanthus savala & $\mathrm{D}$ & $\mathrm{Am}$ \\
\hline 21 & Ambassis kopsii & $\mathrm{D}$ & $\mathrm{Am}$ & 45 & Pseudorhombus arsius & $\mathrm{D}$ & \\
\hline 22 & Epinephelus maculatus & $\mathrm{R}$ & & 46 & Brachirus siamensis & $\mathrm{D}$ & $\mathrm{Am}$ \\
\hline 23 & Pelates quadrilineatus & $\mathrm{D}$ & $\mathrm{Am}$ & 47 & Cynoglossus trigrammus & $\mathrm{D}$ & $\mathrm{Am}$ \\
\hline 24 & Echeneis naucrates & $\mathrm{D}$ & $\mathrm{Am}$ & & & & \\
\hline \multicolumn{8}{|c|}{ Species entering deeply into the river } \\
\hline 1 & Dasyatis akajei - 16 & $\mathrm{R}$ & & 58 & G. limbatus - 17 & $\mathrm{D}$ & $\mathrm{Am}$ \\
\hline 2 & Megalops cyprinoides $\mathrm{VU}-4$ & $\mathrm{R}$ & $\mathrm{Am}$ & 59 & Diagramma picta -16 & $\mathrm{D}$ & $\mathrm{Am}$ \\
\hline 3 & Congresox talabon - 17 & $\mathrm{R}$ & $\mathrm{Am}$ & 60 & Plectorhinchus gibbosus CR - 16 & $\mathrm{D}$ & \\
\hline 4 & Clupanodon thrissa EN - 2, 18 & $\mathrm{D}$ & An & 61 & Pomadasys hasta $-4,16$ & $\mathrm{D}$ & An \\
\hline 5 & Konosirus punctatus VU - 2, 18 & DR & & 62 & Acanthopagrus berda $-4,17$ & $\mathrm{R}$ & $\mathrm{Am}$ \\
\hline 6 & Nematalosa nasus VU - 4, 18 & DR & An & 63 & A. latus $-4,18$ & DR & $\mathrm{Am}$ \\
\hline 7 & Sardinella fimbriata - 16 & $\mathrm{D}$ & & 64 & Parargyrops edita - 16 & $\mathrm{D}$ & $\mathrm{Am}$ \\
\hline 8 & S. gibbosa -4 & $\mathrm{D}$ & & 65 & Rhabdosargus sarba $-2,18$ & DR & $\mathrm{Am}$ \\
\hline 9 & Stolephorus commersonnii - 2, 17 & $\mathrm{D}$ & An & 66 & Argyrosomus macrophthalmus - 16 & $\mathrm{R}$ & \\
\hline 10 & Thryssa dussumieri $-2,16$ & $\mathrm{D}$ & $\mathrm{Am}$ & 67 & Boesemania microlepis - 16 & $\mathrm{D}$ & $\mathrm{Am}$ \\
\hline 11 & T. hamiltonii $-4,17$ & DR & $\mathrm{Am}$ & 68 & Dendrophysa russelli - 16 & $\mathrm{D}$ & $\mathrm{Am}$ \\
\hline 12 & Arius arius $-4,17$ & DR & $\mathrm{Am}$ & 69 & Nibea soldado - 4 & $\mathrm{D}$ & $\mathrm{Am}$ \\
\hline 13 & Plotosus lineatus - 16 & $\mathrm{D}$ & $\mathrm{Am}$ & 70 & Upeneus sulphureus - 2, 16 & $\mathrm{D}$ & \\
\hline 14 & Salanx cuvieri -17 & $\mathrm{R}$ & An & 71 & U. tragula -16 & $\mathrm{R}$ & $\mathrm{Am}$ \\
\hline 15 & Saurida undosquamis - 17 & $\mathrm{R}$ & $\mathrm{Am}$ & 72 & Drepane longimana $-4,16$ & $\mathrm{D}$ & $\mathrm{Am}$ \\
\hline 16 & Strongylura leiura - 16 & $\mathrm{D}$ & $\mathrm{Am}$ & 73 & D. punctata -17 & $\mathrm{D}$ & \\
\hline 17 & S. strongylura $-4,17$ & $\mathrm{D}$ & $\mathrm{Am}$ & 74 & Monodactylus argenteus -16 & $\mathrm{D}$ & \\
\hline 18 & Tylosurus crocodilus - 16 & $\mathrm{D}$ & $\mathrm{Am}$ & 75 & Chelmon rostratus -16 & $\mathrm{D}$ & \\
\hline 19 & Hemiramphus marginatus - 17 & $\mathrm{R}$ & $\mathrm{Am}$ & 76 & Parachaetodon ocellatus VU - 16 & $\mathrm{D}$ & \\
\hline 20 & Hyporhamphus quoyi - 4, 16 & $\mathrm{D}$ & $\mathrm{Am}$ & 77 & Liza carinata $-4,18$ & DR & $\mathrm{Am}$ \\
\hline 21 & Zenarchopterus buffonis - 4, 16 & DR & & 78 & L. subviridis $-4,18$ & DR & $\mathrm{Ca}$ \\
\hline
\end{tabular}




\begin{tabular}{|c|c|c|c|c|c|c|c|}
\hline 22 & Inimicus didactylus - 16 & $\mathrm{D}$ & & 79 & Mugil cephalus - 17 & DR & $\mathrm{Ca}$ \\
\hline 23 & Inegocia japonica - 16 & $\mathrm{D}$ & & 80 & M. strongylocephalus - 17 & DR & $\mathrm{Ca}$ \\
\hline 24 & Platycephalus indicus -16 & $\mathrm{R}$ & & 81 & Abudefduf bengalensis - 16 & $\mathrm{D}$ & \\
\hline 25 & Ambassis buruensis - 17 & $\mathrm{R}$ & & 82 & Callionymus curvicornis - 16 & $\mathrm{D}$ & \\
\hline 26 & A. gymnocephalus - 16 & $\mathrm{D}$ & $\mathrm{Am}$ & 83 & Dactylopus dactylopus - 16 & $\mathrm{D}$ & \\
\hline 27 & A. vachellii $-4,17$ & DR & & 84 & Bostrichthys sinensis $\mathrm{CR}-2$ & $\mathrm{D}$ & $\mathrm{Am}$ \\
\hline 28 & Lateolabrax japonicas $-4,18$ & $\mathrm{DR}$ & $\mathrm{Ca}$ & 85 & Butis butis - 2,17 & DR & $\mathrm{Am}$ \\
\hline 29 & Diploprion bifasciatum -16 & $\mathrm{D}$ & & 86 & Eleotris fusca $-4,16$ & $\mathrm{D}$ & $\mathrm{Am}$ \\
\hline 30 & Epinephelus bruneus - 16 & $\mathrm{D}$ & $\mathrm{Am}$ & 87 & E. melanosoma - 7 & $\mathrm{DR}$ & $\mathrm{Am}$ \\
\hline 31 & E. coioides -16 & $\mathrm{D}$ & & 88 & Acentrogobius caninus - 16 & $\mathrm{D}$ & $\mathrm{Am}$ \\
\hline 32 & E. sexfasciatus -16 & $\mathrm{R}$ & & 89 & A. viridipunctatus $-4,20$ & $\mathrm{R}$ & \\
\hline 33 & P. sexlineatus -16 & $\mathrm{D}$ & $\mathrm{Am}$ & 90 & Glossogobius fasciatopunctatus - 16 & $\mathrm{D}$ & $\mathrm{Am}$ \\
\hline 34 & Rhyncopelates oxyrhynchus - 16 & $\mathrm{R}$ & $\mathrm{Am}$ & 91 & G. giuris $-4,18$ & DR & $\mathrm{Am}$ \\
\hline 35 & Terapon jarbua $-4,16$ & DR & $\mathrm{Ca}$ & 92 & Ctenogobius brevirostris $-2,16$ & DR & $\mathrm{Am}$ \\
\hline 36 & T. theraps -16 & $\mathrm{D}$ & $\mathrm{Am}$ & 93 & Oxyurichthys microlepis - 2 & $\mathrm{R}$ & $\mathrm{Am}$ \\
\hline 37 & Apogon kinesis - 16 & $\mathrm{D}$ & & 94 & O. tentacularis - 16 & $\mathrm{R}$ & $\mathrm{Am}$ \\
\hline 38 & Sillago maculata - 16 & $\mathrm{D}$ & $\mathrm{Am}$ & 95 & Boleophthalmus pectinirostris - 2 & $\mathrm{R}$ & \\
\hline 39 & S. sihama $-4,16$ & $\mathrm{R}$ & $\mathrm{Am}$ & 96 & Periophthalmus modestus -2 & $\mathrm{D}$ & $\mathrm{Am}$ \\
\hline 40 & Carangoides malabaricus - 16 & DR & $\mathrm{Am}$ & 97 & Platax teira -16 & $\mathrm{R}$ & $\mathrm{Am}$ \\
\hline 41 & C. praeustus -16 & $\mathrm{D}$ & & 98 & Scatophagus argus $-4,17$ & DR & $\mathrm{Am}$ \\
\hline 42 & Caranx bucculentus - 2 & $\mathrm{D}$ & & 99 & Siganus canaliculatus -17 & $\mathrm{D}$ & $\mathrm{Am}$ \\
\hline 43 & Gnathanodon speciosus - 16 & $\mathrm{D}$ & & 100 & S. fuscescens - 16 & $\mathrm{D}$ & $\mathrm{Am}$ \\
\hline 44 & Selaroides leptolepis - 16 & $\mathrm{R}$ & $\mathrm{Am}$ & 101 & Sphyraena flavicauda -16 & $\mathrm{D}$ & \\
\hline 45 & Leiognathus bindus - 4 & $\mathrm{R}$ & $\mathrm{Am}$ & 102 & S. jello -16 & $\mathrm{R}$ & $\mathrm{Am}$ \\
\hline 46 & L. daura - 4 & $\mathrm{R}$ & $\mathrm{Am}$ & 103 & Scomberomorus commerson - 16 & $\mathrm{D}$ & \\
\hline 47 & L. equulus -17 & DR & $\mathrm{Am}$ & 104 & Tephrinectes sinensis - 4, 17 & DR & Am \\
\hline 48 & L. lineolatus -17 & $\mathrm{D}$ & $\mathrm{Am}$ & 105 & Brachirus orientalis $-4,17$ & $\mathrm{R}$ & An \\
\hline 49 & L. rivulatus -17 & $\mathrm{D}$ & $\mathrm{Am}$ & 106 & Solea ovata -17 & $\mathrm{R}$ & $\mathrm{Am}$ \\
\hline 50 & Secutor ruconius -17 & $\mathrm{D}$ & $\mathrm{Am}$ & 107 & Zebrias zebra - 16 & $\mathrm{D}$ & $\mathrm{Am}$ \\
\hline 51 & Lutjanus fulviflamma - 16 & $\mathrm{R}$ & $\mathrm{Am}$ & 108 & Cynoglossus cynoglossus - 4 & $\mathrm{R}$ & $\mathrm{Am}$ \\
\hline 52 & L. johnii - 16 & $\mathrm{D}$ & & 109 & C. microlepis - 16 & $\mathrm{D}$ & $\mathrm{Am}$ \\
\hline 53 & L. russellii - 16 & $\mathrm{D}$ & & 110 & C. puncticeps -16 & $\mathrm{R}$ & \\
\hline 54 & Caesio cuning - 16 & $\mathrm{D}$ & & 111 & Triacanthus biaculeatus -16 & $\mathrm{D}$ & Am \\
\hline 55 & Gerres erythrourus -17 & $\mathrm{D}$ & & 112 & Monacanthus chinensis -16 & $\mathrm{R}$ & \\
\hline 56 & G. filamentosus - 17 & $\overline{\mathrm{DR}}$ & $\mathrm{Am}$ & 113 & Chelonodon patoca -16 & DR & $\mathrm{An}$ \\
\hline 57 & G. japonicas -17 & $\mathrm{D}$ & $\mathrm{Am}$ & & & & \\
\hline
\end{tabular}

Notes: D: dry season; R: rainy season; DR: both seasons. An (Anadromy): live in the sea, migrate into rivers for spawning (sea-river); $\mathrm{Ca}$ (Catadromy): live in rivers, migrate to the sea for spawning (riversea); and Am (Amphidromy): live in rivers, spawn in rivers, but early stages inhabit the sea-freshwater amphidromy or live in the sea, spawn in the sea, but early stages inhabit rivers-marine amphidromy (McDowall, 1988). VU, EN and CR: levels in Vietnam Red Data Book, part of Animals (2007). Numbers in column "Scientific name" indicate stations where fish were recorded (see figure 1).

Table 2. Seasonal entering of marine fishes in the $\mathrm{Ba}$ Che and Tien Yen rivers

\begin{tabular}{|c|c|c|c|c|c|c|c|c|c|c|c|c|}
\hline Sections & \multicolumn{6}{|c|}{ Downstream } & \multicolumn{6}{|c|}{ Middle area } \\
\hline Season & Dry & Rain & Year & Dry & Rain & Year & Dry & Rain & Year & Dry & Rain & Year \\
\hline Ba Che & \multicolumn{3}{|c|}{ Nam Son $(6 \mathrm{~km})$} & \multicolumn{3}{|c|}{ Ba Che Weir $(15 \mathrm{~km})$} & \multicolumn{3}{|c|}{ Khe Tam $(20 \mathrm{~km})$} & \multicolumn{3}{|c|}{ Khe Nhang $(30 \mathrm{~km})$} \\
\hline $\begin{array}{l}\text { Salinity } \\
(\% \text { ) }\end{array}$ & \multicolumn{2}{|c|}{$\begin{array}{c}\text { Dry: } \\
0.4-19.0\end{array}$} & $\begin{array}{l}\text { Rain: } \\
0.0-4.3\end{array}$ & $\begin{array}{c}\text { Dry: } \\
0.0-10.0\end{array}$ & \multicolumn{2}{|c|}{$\begin{array}{c}\text { Rain: } \\
0.0-3.0\end{array}$} & \multicolumn{3}{|c|}{0} & \multicolumn{3}{|c|}{0} \\
\hline $\begin{array}{l}\text { Species } \\
(43)\end{array}$ & 31 & 24 & 11 & 19 & 14 & 4 & 1 & 0 & 0 & 0 & 0 & 0 \\
\hline Tien Yen & \multicolumn{3}{|c|}{$\begin{array}{l}\text { Tien Yen Weir } \\
(10 \mathrm{~km})\end{array}$} & \multicolumn{3}{|c|}{ Yen Than $(20$ km) } & \multicolumn{3}{|c|}{ Khe Soong (15 km) } & \multicolumn{3}{|c|}{ Dien Xa (25 km) } \\
\hline $\begin{array}{l}\text { Salinity } \\
(\%)\end{array}$ & \multicolumn{2}{|c|}{\begin{tabular}{c|} 
Dry: \\
$1.7-21.8$
\end{tabular}} & $\begin{array}{l}\text { Rain: } \\
0.0-4.3\end{array}$ & \multicolumn{2}{|c|}{$\begin{array}{c}\text { Dry: } \\
0.0-17.0\end{array}$} & $\begin{array}{l}\text { Rain: } \\
0.0-4.0\end{array}$ & \multicolumn{2}{|c|}{$\begin{array}{c}\text { Dry: } \\
0.0-0.2\end{array}$} & Rain: 0 & \multicolumn{3}{|c|}{0} \\
\hline $\begin{array}{l}\text { Species } \\
(103)\end{array}$ & 77 & 45 & 19 & 27 & 17 & 6 & 9 & 1 & 0 & 0 & 1 & 0 \\
\hline
\end{tabular}


Of 113 intrusion marine fish species, 84 were collected in the dry season $(60$ species only in this season), 53 in the rainy season (29 species only in this season) and 24 in both seasons (Table 1). Hence, of 160 marine fish species in the downstream, 119 occurred in the dry season, 68 in the rainy season and 27 in both seasons. In the rainy season, few marine fish species were found as the salinity was low and frequently changing.

In the dry season, salinity in the downstream areas of the two rivers ranged from 0.4 to $21.8 \%$ (Table 2); and this value at $\mathrm{Ba}$ Che bridge and Mui Chua was between 3 and $27 \%$. This condition was suitable for euryhaline or stenohaline fishes entering into the rivers for feeding, such as $R$. acutus, $D$. akajei, $D$. bennetti, $S$. commerson, $T$. biaculeatus, M. chinensis, C. patoca and species of Soleidae and Cynoglossidae. However, true estuarine fish species were dominant, including several marine fishes that adapt well to swift changes of salinity in the downstream areas and estuaries, and they become residents of the area. Common representatives of this group were A. vulpes, C. thrissa, K. punctatus, S. leiura, $H$. quoyi and many species of Sciaenidae, Leiognathidae, Gerridae, Lutjanidae, Sparidae, Teraponidae, Mullidae, Drepanidae, Siganidae and Eleotridae (Table 1). True estuarine fish and euryhaline as well as stenohaline fish are the main fisheries resources of estuarine and coastal waters (Vu Trung Tang, 2009). The above information has practical implications for exploitation and protection of fishery resources in the study site.

Of 160 marine fish species, 91 were amphidromous (Froese \& Pauly, 2019), which are categorized as marine amphidromy (McDowall, 1988) (Table 1). There were 9 anadromous and 5 catadromous fish species in the study site (McDowall, 1988). Thus, of 160 marine fish species, except for 105 migratory fish, 55 (18 species only in lower reaches and 37 species could enter deeply into the rivers) (Table 1) were not diadromous fish but frequently occurred in the study site. This case could relate to estuarine features that had a large tidal range and deep intrusion of seawater, bearing suitable conditions to their occurrences for feeding.

According to Ta et al. (2011), based on monthly surveys from November 2010 to February 2011 in the Tien Yen estuary, 33 species of fish were recorded as larval and juvenile stages. Among them, 13 species were also recorded in the present study, i.e., $K$. punctatus, Z. buffonis, S. cyanospilos, $S$. marmoratus, A. buruensis, L. japonicus, $S$. maculata, S. sihama, A. latus, $R$. sarba, B. butis and Z. zebra. Therefore, this estuary is not a habitat only for frequent residents but also a nursery ground for larvae and juveniles of many marine fishes.

In addition to marine fish migrating into the downstream and becoming frequent residents, some freshwater could move down to brackish waters to live, such as $P$. dispar and $S$. affinis in the $\mathrm{Ba}$ Che River, and Oryzias curvinotus (Tran \&Ta, 2014, 2016), $P$. altivelis (Tran et al., 2017, 2018a) in the Tien Yen River.

The number of marine fish migrating into rivers for feeding and spawning was, therefore, more dominant than those of freshwater fish moving to the estuaries or to the sea. Intensive salinity intrusion, high and relatively substantial salinity would have been the main causes for the migrations into rivers of marine fish and the limitation into brackish and seawater of freshwater fish. Furthermore, food sources in rivers from tropics are more abundant than those in marine environments (Gross, 1987). As a result, many marine fish, primarily euryhaline ones occasionally enter into rivers for feeding, and gradually become permanent residents herein, and eventually form amphidromous fishes (Gross, 1987).

\section{Distribution of fish in the Vietnam Red Data Book, unidentified and new records}

\section{Fish in the Vietnam Red Data Book (2007)}

In the Ba Che and Tien Yen Rivers, 12 species ( 9 marine fish and 3 freshwater fish) were listed in the Vietnam Red Data Book 
(part of Animals, 2007) (Ministry of Science and Technology of Vietnam, 2007; Tran \& Ta, 2014). These species belonged to 12 genera, 10 families and 6 orders. The highest number of rare fish were from family Clupeidae (3 species) and order Perciformes (4 species). Two species placed at the CR level ( $P$. gibbosus and B. sinensis) were collected in both the river basins. Number of rare fish increased from upstream (2 species) to downstream (10 species) and 1 to 7 species per station, being highest in Mui Chua with 7 species. Ten stations had only 1 species for each (Figure 6).

All 12 species were distributed in rivers (including 3 species in streams) and none of such fish were recorded in rice field, ponds and lakes. Two species occurred in both seasons, 10 only in the dry season and none of the species could be collected only in the rainy season. $P$. vuquangensis and $C$. maculata had a wide distribution range, in 11 and 9 stations, respectively. Other species were recorded from 1 to 6 stations (Figure 6).

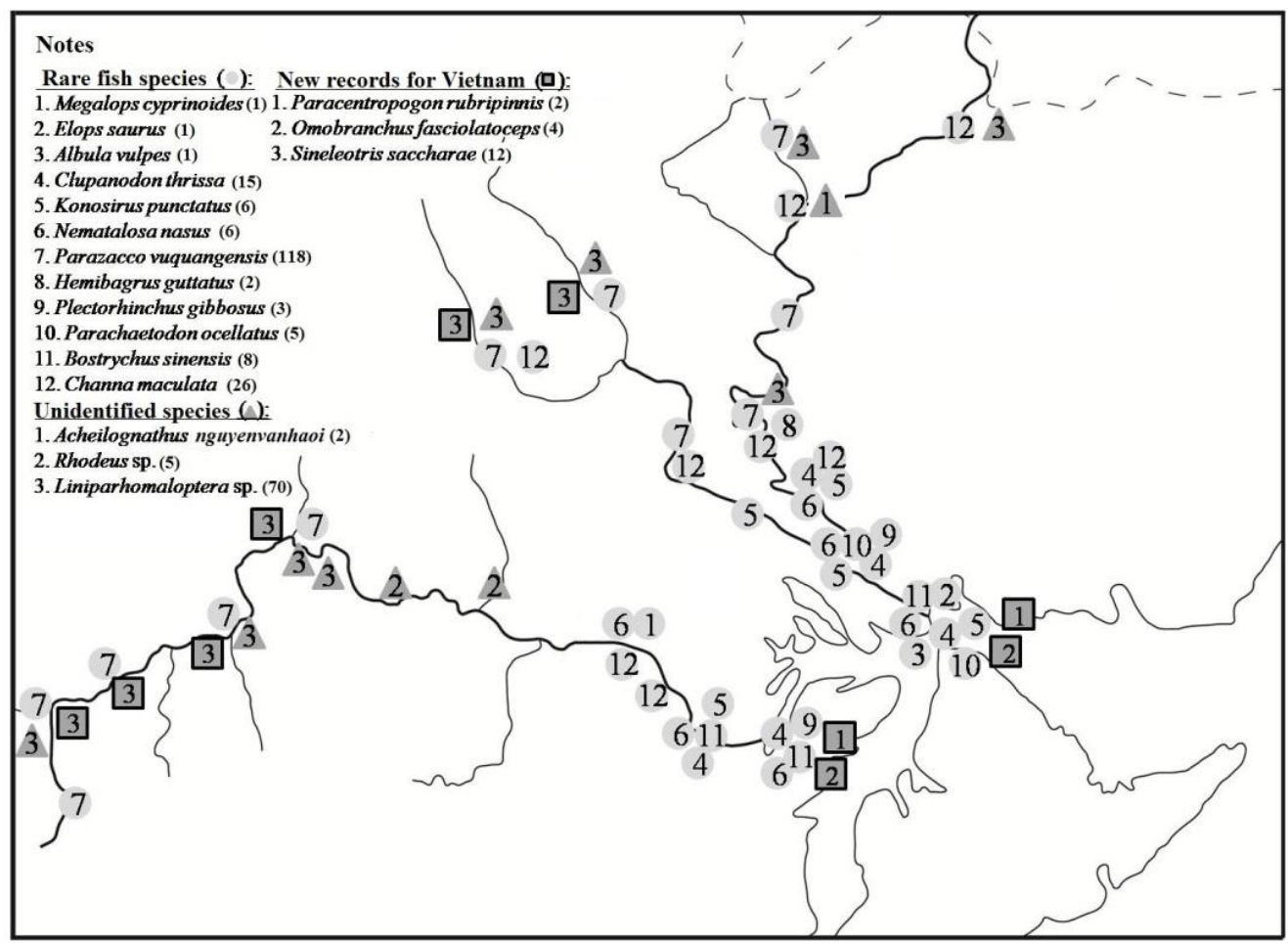

Figure 6. Distribution of fish in Vietnam Red Data Book, unidentified and new records for Vietnam in the $\mathrm{Ba}$ Che and Tien Yen rivers. Numbers within brackets after each species indicate number of collected individuals

Based on the wide range and number of individuals of $P$. vuquangensis and $C$. maculata, further investigations need to be examined to assess the level of protections of these two species in the study site.

\section{Unidentified and new records for Vietnam}

Two unidentified freshwater species (Rhodeus sp. and Liniparhomaloptera sp.) were distributed in the middle and downstream in the dry seasson. Liniparhomaloptera sp. had a wider distributional range, in 9 stations (Figure 6).

Of three additional records for Vietnam, $P$. rubripinnis (in the rainy season) and $O$. fasciolatoceps (in the dry season) were collected in two stations of the downstream and $S$. saccharae (in the dry season) in 6 
stations of the upstream. New species, $A$. nguyenvanhaoi (Nguyen Huu Duc et al., 2013) was collected in the dry season from the Tien Yen River (Figure 6).

In short, in the study site, the downstream area is the place mainly for rare fish listed in the Red Data Book of Vietnam and new records for Vietnam, whereas the middle and upstream of rivers are a high potential of biodiversity, with many species that might be new for science. These data are precious for conservation and development of fishery resources in the study site.

\section{CONCLUSION}

In the $\mathrm{Ba}$ Che and Tien Yen Rivers, the ichthyo-fauna and distributional patterns of fish were characterized for coastal areas as marine fishes outweighed freshwater fishes, probably due to the deep salinity intrusion, especially in the dry season, which leads to be higher and unchangeable salinity. Fish intended to be distributed in the downstream and estuaries, including species listed in the Vietnam Red Data Book and new records for Vietnam.

\section{REFERENCES}

Dang Ngoc Thanh, Ho Thanh Hai, 2007. Fundamentals of aquatic biology. Natural Science and Technology Publishing House, Ha Noi. (in Vietnamese).

Duong Quang Ngoc, 2007. Contribution to study of ichthyo-fauna in the Ma river basin belonging to Vietnam. PhD Thesis of Biology, Hanoi National University of Education. (in Vietnamese).

Gross M., 1987. Evolution of diadromy in fishes. American Fishes Society Symposium, 1: 14-25.

Froese R., Pauly D. eds., 2019. FishBase. World Wide Web electronic publication. www.fishbase.org (version 12/2019).

Hammer Ø., Harper D. A. T., Ryan P. D., 2001. PAST: Paleontological statistics software package for education and data analysis. Palaeontol. Electron., 4(1): 9 pp.
McDowall R.M., 1988. Diadromy in fishes: migrations between freshwater and marine environments, Croom Helm, London.

Ministry of Fisheries, 1996. Fisheries Resources of Vietnam. Aquaculture Publishing House, Ha Noi. 615 pp. (in Vietnamese).

Ministry of Science and Technology of Vietnam, 2007. Vietnam's Red Data Book, Part I. Animals. Natural Science and Technology Publishing House. pp. 277-372. (in Vietnamese).

Nelson J. S., 2006. Fishes of the World, 4th edn, Wiley, Hobken, NJ.

Nguyen Huu Duc, Tran Duc Hau, Ta Thi Thuy, 2013. A new species of genus Acheilognathus Bleeker, 1859 from the Tien Yen River, Vietnam. Journal of Biology, 35(1): 18-22. (in Vietnamese with English summary).

Nguyen Van Au, 1997. Rivers of Viet Nam. Viet Nam National University Press, Ha Noi. (in Vietnamese).

Nguyen Van Hao, Ngo Sy Van, 2001. Freshwater fsh of Vietnam, Vol. 1. Aquaculture Publishing House, Ha Noi. 622 pp. (in Vietnamese).

Ta Thi Thuy, Do Van Nhuong, Tran Duc Hau, Nguyen Xuan Huan, 2011. Composition and distribution of fish in Ba Che River, Quang Ninh Province. Journal of Biology, 33(4): 18-27. (in Vietnamese with English summary).

Ta T. T., Tran D. H., Kinoshita I., Sashida M., Azuma K., 2011. Larvae and juvenile ichthyofauna of the estuaries of the northern Vietnam, ISJ Meeting 44th, Hirosaki, Japan.

Ta Thi Thuy, Tran Duc Hau, Nguyen Xuan Huan, Do Van Nhuong, Pham Thi Thanh $\mathrm{Tu}, 2010$. Fish species in the Tien Yen River belonging to Tien Yen District, Quang Ninh Province. Journal of Science, Natural Sciences and Technology, 26(2S): 237-246. (in Vietnamese with English summary). 
Ta T. T., Ta T. P., Nguyen X. H., 2018. Additional data of diversity of fish species in the Tien Yen estuary, Quang Ninh Province. Scientific Journal of Hanoi Metropolitan University, 27: 134-144.

Tran D. H., Iida M., Maeda K., 2017. Downstream migration of newly-hatched ayu (Plecoglossus altivelis) in the Tien Yen River of northern Vietnam. Environ. Biol. Fish., 100: 1329-1341.

Tran D. H., Kinoshita I., Nguyen X. H., Miller T. W., Ta T. T., Tran T. T., 2018a. Early life stages and habitats of the Ayu (Plecoglossus altivelis) based on data from the southernmost populations in two river-estuary systems in Vietnam. Asian Fish. Sci., 31(1): 1-16.

Tran Duc Hau, Pham Thi Thao, 2017. Morphological description of early stages of three species belonging to Clupeiformes from the Kalong and Tien Yen estuaries, Vietnam. Journal of Biology, 39(2): 142-151. (in Vietnamese with English summary).

Tran D. H., Ta T. T., 2014. Fish diversity and fishery status in the $\mathrm{Ba}$ Che and Tien Yen Rivers, northern Vietnam, with consideration on factors causing recent decline of fishery products. Kuroshio Science, 7(2): 113-122.
Tran D. H., Ta T. T., 2016. Dependence of Hainan medaka, Oryzias curvinotus (Nichols \& Pope, 1927), on salinity in the Tien Yen estuary of northern Vietnam. Anim. Biol., 66(1): 49-64.

Tran D. H., Tran T. T., Ta T. T., 2016. Occurrence of Hypoatherina valenciennei (Bleeker, 1854) post-larvae and juveniles collected at estuarine habitats of northern Vietnam. Trop. Nat. Hist., 16(2): 107-117.

Tran T. T., Tran D. H., Chu H. N., Ta T. T., 2018b. Habitat segregation of Gerres japonicus and G. limbatus in early stages in the Tien Yen estuary, northern Vietnam. Journal of Biology, 40(4): 133141.

Tran Tuat, Tran Thanh Xuan, Nguyen Duc Nhat, 1987. Hydrographic geography of rivers in Vietnam. Science and Technics Publishing House, Ha Noi. (in Vietnamese).

$\mathrm{Vu}$ Trung Tang, 2008. Ecology of aquatic ecosystems. Education Publishing House, Ha Noi. (in Vietnamese).

Vu Trung Tang, 2009. Estuarine ecosystems of Vietnam (Exploitation, Maintenance and Management Resources for Sustainable Development). Education Publishing House, Hanoi. 269 pp. (in Vietnamese). 